\title{
EFFECT OF SOME POWDERS AND HIVE PRODUCTS ON LARVAL HAEMOLYMPH OF SILKWORM Abdel-Rahman,Y.A. ; ${ }^{1}$ M.H.Hussein ${ }^{2}$; S. H. Rateb ${ }^{2}$ and R.E. Hassan ${ }^{1}$ 1- Plant Prot. Dept., Fac. of Agric., Al-Azhar Univ., Assiut. 2- Plant Prot. Dept., Fac. of Agric., Assiut University.
}

\begin{abstract}
Two doses (5 and $10 \mathrm{gms}$ ) of 14 powders (hive products and plant materials) were added to mulberry leaves, and two levels (\%) of 14 liquid treatments (hive products, honey, pollen, royal jelly and propolis and their mixtures) were sprayed on mulberry leaves which feed to $4^{\text {th }}$ and $5^{\text {th }}$ instar larvae of silkworm. Effects on haematological characters, Total Soluble Solids \% (T.S.S.\%), Total Haemocyte Counts $/ \mathrm{mm}^{3}$ haemolymph (T.H.C.), and Differential Haemocytes Counts \% (D.H.C.\%), were studied in $5^{\text {th }}$ instar larval haemolymph. The best tested powders $(\mathrm{gm})$, and liquids (\%), with respect to (T.S.S.\%) can be arranged desindinglly as follow: Palm Pollen, hand-collected (10 gm), Pollen from honey bee colonies (10 gm). Drone brood, dried (5 gm), Soya flour, defatted (10 gm), Pollen (0.3\%), Pollen (5 gm), Royal Jelly $(0.03 \%)$, and Honey $(1 \%)$. This depends on $\%$ increment of these treatments over control. Concerning (T.H.C.), the best treatments were: Palm Pollen (10 or 5 gms), Pollen (10 gm), Royal Jelly $(0.02 \%)$, Pollen $(0.2 \%)$, Pollen + Propolis $(0.2 \%+$ $0.1 \%$ ), and Drone Brood (5 or $10 \mathrm{gms}$ ). Powder treatment was more effective as compared with liquid treatment, with respect to T.S.S.\% and T.H.C. Prohaemocytes $\%$, was higher in Pollen $(0.2 \& 0.3 \%)$ and its mixture with Royal Jelly $(0.2 \%+0.02 \%)$, Plasmatocytes $\%$, Granular cells $\%$, and Oenocytoides $\%$, were in Pollen + Honey $(0.2 \%+2 \%) ;$ Pollen + Propolis $(0.2 \%+0.1 \%)$ and Honey + Royal Jelly $(2 \%+0.02 \%)$, treatments, respectively, while Spindle cells \% were more in control, as compared with all tested liquid treatments. In powder treatments (gm), maximum \% abundance of prohaemocytes was in Pollen (5 \& $10 \mathrm{gms}$ ), Soya (5 \& $10 \mathrm{gm}$ ), Palm Pollen (5 \& 10 $\mathrm{gms}$ ) and Drone Brood (10 gms). Maximum \% abundance of other haemocytes types, was noticed with powders from Vasaka, Buddleia, and Spearmint leaves. Statistical analysis of obtained data revealed highly significant differences between treatments and used doses, and these data were discussed.
\end{abstract}

\section{INTRODUCTION}

Insect haemolymph contains haemocytes suspended in plasma. Haemocytes have essential roles in numerous physiological activities (Wigglesworth, 1959). This fluid reflects physiological or pathological condition of the insect (Kostecki, 1965).

Effects of different factors or treatments on the larval haemolymph of silkworms were studied by many researchers: Radwan, 1978; El-Deeb, 1981; Horrie and Watanbe, 1983; Salem et al., 1985a,b; Abd El-Naby, 1988; Reddy et al., 1991; Thyagaraja et al., 1991; Ashour, 1997; Eid et al., 1999; Abdellah, 2007; Rateb et al., 2010; Kumar and Michael, 2011 and Manjula et al., 2011.

This work aims to study the effects of 14 powders and hive products with mulberry leaves on total soluble solids (\%), total counts of haemocytes $/ \mathrm{mm}^{3}$ in $5^{\text {th }}$ (T.H.C.) and (D.H.C.\%) instar larval haemolymph of local silkworm. 


\section{MATERIALS AND METHODS}

Fourteen powder treatments were used with mulberry leaves in feeding of $4^{\text {th }}$ and $5^{\text {th }}$ instars of silkworm. They were: pollen (from pollen trap soya flour (defated), dried drone brood, palm pollen (hand-collected), ascorbic acid, lantana, eucalyptus, basil, spearmint, thyme, ziziphus, buddleia, Vasaka, and guava. Two levels, 5 and $10 \mathrm{gm}$, were used for each treatment.

Fourteen hive products liquid treatments were used with mulberry leaves for feeding of $4^{\text {th }}$ and $5^{\text {th }}$ instars of silkworm. They were: bee honey ( 1 and $2 \mathrm{gms})$; royal jelly (0.02 and $0.03 \mathrm{gm})$; propolis ( 0.1 and $0.2 \mathrm{gm})$; pollen $(0.2$ and $0.3 \mathrm{gm})$; pollen + royal jelly $(0.2+0.02 \mathrm{gm})$; pollen + honey $(0.2+2$ $\mathrm{gm})$; pollen + propolis $(0.2+0.1 \mathrm{gm})$; honey + propolis $(2+0.1 \mathrm{gm})$; honey + royal jelly $(2+0.02 \mathrm{gm})$; and propolis + royal jelly $(0.1+0.02 \mathrm{gm})$. Two concentrations were used for each treatment.

Every tested powder or liquid was replicated three times in three carton boxes, each contain 50 larvae. Feeding with treated leaves was conducted four times/day. Control larvae were fed with untreated mulberry leaves was used with $100 \mathrm{ml}$ distilled water.

A simple method adopted by (Hussein, 1978) using hand refractometer was used for determination of total soluble solids (\%) in 5 dayold of $5^{\text {th }}$ instar larval haemolymph. Total counts of haemocytes in larval haemolymph was conducted as described by (Predtetshensky et al., 1950) and (D.H.C.\%) as described by (Jones, 1967).

Means of tested haematological characters, and \% over control readings, were calculated. Statistical analysis was carried out to compare the obtained means of studied parameters.

\section{RESULTS AND DISCUSSION}

Data of the effect of powder treatments on Total Soluble Solids \% (T.S.S.\%), Total Haemocytes Counts $/ \mathrm{mm}^{3}$ haemolymph (T.H.C. $/ \mathrm{mm}^{3}$ ), and Differential Haemocytes Counts \%, or types of haemocytes (D.H.C.\%) and \% over control of these data, in $5^{\text {th }}$ instar larval haemolymph of silkworm are summarized in Table (1).

Maximum (T.S.S.\%) in larval haemolymph, and (\% over control), in five grams-powder treatments was $13.86 \%$, or $(31.25 \%) ; 13.74 \%$, or $(30.113 \%)$; and $12.9 \%$ or $(22.159 \%)$, in palm pollen, soya flour, and pollen, respectively. While, in 10 grams-powder treatments, maximum mean (T.S.S.\%) was $14.37 \%$ or $(42.842 \%) ; 13.78 \%$, or $(36.978 \%) ; 13.3 \%$, or $(32.206 \%)$; and $13.29 \%$, or (32.107\%), in palm pollen, pollen, drones brood, and soya, respectively.

Higher figures of T.S.S.\% in haemolympy, which reflects more active physiological condition was noticed in 10 grams-powder treatments, followed by 5 grams-treatments, with palm pollen, soya, pollen and drones brood. The effect of soya on increasing (T.S.S.\%) in silkworm, was also noticed by Rateb et al. (2010), and by Manjula et al. (2011), with, other legume plant cowpea. 
J. Plant Prot. and Path., Mansoura Univ., Vol. 3 (5), May, 2012 
Abdel-Rahman, Y.A. et al.

(T.S.S.\%) in larval haemolymph was less than control in the following treatments: basil $(10 \mathrm{gm})$, spearmint (5 and $10 \mathrm{gms})$, Buddleio (5 and 10 gms), and vaska ( $5 \mathrm{gm})$. The same was noticed in (T.H.C.), with basil, spearmint and buddleia. During this work (T.S.S.\%) was ranged from 9.02\% to 14.37 , while it ranged from $9.335 \%$ to $11.295 \%$ as reported by Ahmed (1999), and $7.640 \%$ to $10.073 \%$ as reported by Abdellah (2007) and 9.107 to $10.594 \%$ as reported by Rateb et al. (2010).

Maximum (T.H.C. $/ \mathrm{mm}^{3}$ haemolymph) and (\% over control) was 259 blood cells, or (119.39\%), and 2736 cells, or (149.18\%), in $5 \mathrm{gms}$, and 10 grams palm pollen treatments, respectively, followed by treatments of pollen, soya, and drone brood, in two tested levels. The same was observed in respect to T.S.S.\%.

More positive effect on (T.S.S\%) and (T.H.C.), as a result of using plant powders was noticed in case of eucalyptus they are, and guava treatments, as compared with other plant powders, such as lantana, ziziphus, basil, spearmint, buddleia and Vasaka.

(T.H.C./ $\mathrm{mm}^{3}$ haemolymph) was less than control figures in the following treatments basil (5 \& $10 \mathrm{gms}$ ), spearmint ( 5 \& $10 \mathrm{gms}$ ) and buddleia $(10 \mathrm{gm})$. This reflects disturbance in physiological condition of silkworm. The same was noticed by Kumar and Michael (2011). They noticed that (T.H.C.) were decreased by $15 \%$ after infection of silkworm by flacherie.

Highly significant increment \% in T.S.S. \% was detected in pollen palm pollen, ascorbic acid and drone brood treatments, at $5 \mathrm{gm}$ level, as compared with control.

T.H.C. $/ \mathrm{mm}^{3}$ haemolymph increase in the aforementioned treatments, in addition to eucalyptus and guava treatments, as compared with control, at 5 and 10 gms levels. No significant differences in (T.H.C.) were observed between tested doses in all used powder treatments.

Concerning (D.H.C.\%), maximum prohaemocytes \%, or $83.1 \%$ and $84.5 \%$, counts was detected in pollen (5 and $10 \mathrm{gms}$ ) treatment, respectively. It is well known that prohaemocytes formation leads to production of all other types of haemocytes. Prohaemocytes were increased also in soya (5 and 10 gms), palm pollen (5 and $10 \mathrm{gms}$ ), and drone brood (10 gms), treatments, while it was lower than control, which reflects less activation of physiological condition, in the following treatments: Lantana ( $5 \mathrm{gm})$, basil (5 and $10 \mathrm{gms})$, spearmint (5 and $10 \mathrm{gms})$, thyme (5 gm), buddleia (5 gm) and Vasaka (5 and $10 \mathrm{gms})$.

Maximum increment of plasmatocytes \% was in basil $(5 \mathrm{gm})$ and spearmint (10 gms) treatments. Maximum increase of spindle cells was noticed in Vasaka $(5 \mathrm{gm})$, and buddleia $(10 \mathrm{gms})$ treatments. Highest \% abundance of granular cells was noticed in control of $5 \mathrm{gms}$ dose treatments, and in vasaka (10 gms) treatment. Maximum percentage of oenocytoides, the largest blood cells types, was found in spearmint (10 gms) treatment.

It is of interest to note that increment of prohaemocytes in pollen (hive product), soya, palm pollen and drone brood (hive product) treatments leads to less abundance \% of other four types of haemocytes.

Highly significant differences in prohaemocytes and granular cells were detected between all used treatments and concentrations. 
Highly significant differences were detected between treatments with plasmatocytes, spindle cells and oenocytoides. Highly significant differences in prohaemocytes \%, in palm pollen, soya and pollen treatments, at $5 \mathrm{gm}$ and $10 \mathrm{gms}$ level, and control. Significant differences between abundance of other types of haemocytes and control, were detected. Highly significant increase \% of oenocytoids \%, over control, were detected in treatments of buddleia, spearmint, basil and drone brood.

Data in Table 2 show the effect of hive products (honey, royal jelly, propolis, pollen and their mixture) on haematological characters (T.S.S.\%, T.H.C. and D.H.C.\%) of $5^{\text {th }}$ larval instar of silkworm.

Maximum (T.S.S.\%) and (\% over control) was $13.08 \%$, or $(30.019 \%)$, $12.27 \%$ or $(21.998 \%)$; and $11.66 \%$, or $(15.904 \%)$, in pollen $(0.3 \mathrm{gm})$, royal jelly $(0.03 \mathrm{gm})$ and honey $(1 \mathrm{gm})$, respectively, followed by pollen $(0.2 \mathrm{gm})$, and its mixture with royal jelly $(0.2+0.02 \mathrm{gm})$. Reading of T.S.S.\%, were less than control in the following treatments: honey $(2 \mathrm{gm})$, propolis $(0.2 \mathrm{gm})$ and their mixture $(2+0.1 \mathrm{gm})$.

Highly significant differences in (T.S.S.\%) were noticed between control and all liquid treatments, except in honey $(2 \mathrm{gm})$ and its mixture with royal jelly or propolis treatments.

Concerning total haemocytes counts $/ \mathrm{mm}^{3}$ haemolymph (T.H.C.), maximum numbers of haemocytes and (\% over control) were: 2353 cell, or $(99.237 \%) ; 2345$ cell, or $(98.56 \%)$; and 2333 cell, or $(97.544 \%)$, in royal jelly $(0.02 \mathrm{gm})$; pollen $(0.2 \mathrm{gm})$ and pollen + propolis $(0.2+0.1 \mathrm{gm})$ treatments, respectively.

(T.H.C.), were less than control in the following treatments: propolis $(0.2 \mathrm{gm})$, honey $(2 \mathrm{gm})$, and its mixture with pollen $(0.2 \mathrm{gm})$, or propolis $(0.1$ $\mathrm{gm})$, or royal jelly (0.02 gm).

Thus, depends on data of the effect of honey (2 $\mathrm{gm}$, or $2 \%$ ) concerning (T.S.S.\%) and (T.H.C.), and its mixture with pollen $(0.2 \%)$, propolis $(0.1 \%)$, and royal jelly $(0.02 \%)$, this dose of honey $(2 \%)$, and its mixtures with other hive products, not recommended for using as additives to mulberry leaves for feeding of silkworm. This from the haematological point of view.

Highly significant increment in (T.H.C.), over control, in the following treatments: honey ( 1 and $1 \mathrm{gms})$, royal jelly $(0.03 \mathrm{gm})$, pollen $(0.2 \mathrm{gm})$, and propolis $(0.1 \mathrm{gm})$. Significant decrease in (T.H.C.) was detected in royal jelly $(0.02 \mathrm{gm})$, pollen + propolis, royal jelly plus pollen or propolis, as compared with control.

Maximum abundance \% of prohaemocytes was noticed in pollen $(0.2 \%$ and $0.3 \%)$, and its mixture with royal jelly $(0.2 \%$ and $0.02 \%)$ treatments, and their \% abundance in all tested treatments were more than control. Maximum \% abundance of plasmatocytes, granula cells and oenocytoides, were in treatments of: pollen + honey $(0.2 \%+2 \%)$; pollen + propolis $(0.2 \%+0.1 \%)$; and honey + royal jelly $(2 \%+0.02 \%)$, respectively, while spindle cells \% were more in control, as compared with tested treatments. 
Abdel-Rahman, Y.A. et al.

2 
Kumar and Michael (2011) reported that prohaemocytes and granular cells, which for the bulk of haemocytes, were not influenced by Bacillus thuringensis, while plasmatocytes were significantly increased.

Highly significant increase \% in prohaemocytes was noticed in pollen (2\%) treatment. Highly significant increment \% in plasmatocytes in all treatments, except, pollen + honey, royal jelly + honey and propolis $(0.1 \%)$, as compared with control. Highly significant increase \%, as compared with control, was noticed in spindle cells, in all treatments, except: propolis $(0.2 \%)$, and its mixture with pollen or honey. Granula cells were increased significantly in propolis $(0.2 \%)$, honey $(2 \%)$, and propolis + pollen treatments, as compared with control. Oenocytoids \%, were significantly decreased, as compared with control, in propolis $(0.2 \%)$, pollen $(0.3 \%)$, pollen plus honey or propolis treatments.

From obtained data in Table 1 and 2, and with respect to (T.S.S.\%) in silkworm larval haemolymph, and depending of \% increase over control readings, the tested powders (gm) and liquids (\%) can be arranged desindinglly as follow: palm pollen $(10 \mathrm{gm})$, pollen $(10 \mathrm{gm})$, drone brood (5 $\mathrm{gm})$, soya $(10 \mathrm{gm})$, palm pollen $(5 \mathrm{gm})$, soya $(5 \mathrm{gm})$, pollen $(0.3 \%)$, pollen (5 $\mathrm{gm})$, royal jelly $(0.03 \%)$, and honey $(1 \%)$.

Thus, it can be concluded that using of powders for fortification, or as additives, to mulberry leaves is better than using of liquids, with respect to (T.S.S.\%), an indicator of insect physiological condition, in larvae of silkworm. The same conclusion was obtained by Rateb et al. (2010).

From Table 1 and 2, \% over control, of T.H.C. $/ \mathrm{mm}^{3}$, can be arranged desindinglly as follow: palm pollen (10 or $5 \mathrm{gms}$ ), pollen (10 gm), royal jelly $(0.02 \%)$, pollen $(0.2 \%)$; pollen + propolis $(0.2 \%+0.1 \%)$, and drone brood $(5$ or $10 \mathrm{gms}$ ).

It can be concluded, as with (T.S.S.\%), that concerning (T.H.C.), using of powders is better than liquids as additives to mulberry leaves. The same was observed by Abdellah (2007) and Rashwan (2010).

\section{REFERENCES}

Abdellah, E.E. (2007): Studies on some factors affecting growth and productivity of mulberry silkworms (Bombyx mori L.). M.Sc. Thesis, Assiut Univ., $138 \mathrm{pp}$.

Abd El-Nabi, S.M.M. (1988): Activation of silk secretion in silkworms Philosamia ricini and Bombyx mori after applying antibiotics. Ph.D., Cairo Univ., $124 \mathrm{pp}$.

Ahmed, A.M. (1999): Improving the silkworm productivity in Assiut area. Msc. Thesis. Assiut Univ., $96 \mathrm{pp}$.

Ashour, A.T. (1997): Effect of feeding and hormonal treatments on some biological and physiological parameters of silkworms Bombyx mori and Philosamia ricini. Ph.D., Cairo Univ., 110 pp.

Eid, M.A.A., Souad M. Mahmoud and S.A.S. El-Maasarawy (1999): Effect of antibiotics on the haemocytes of the silkworms Philosamia ricini and Bombyx mori L. XVIII ${ }^{\text {th }}$ ISC Congress 12-16 October 1999, 403. 
El-Deeb, A.S. (1981): Biological and physiological studies on Philosamia ricini Boisd. M.Sc. Thesis, Faculty of Science, Alexandria University.

Horie, Y. and K. Watanabe (1983): Effect of various kinds of dietary protein and supplementation with limiting amino acids on growth, haemolymph components and uric acid excretion in the silkworm, Bombyx mori. J. Insect Physiol. Vol. 29 (2): 157-198.

Hussein, M.H. (1978): Haematological studies on some lepidopterous larvae. $4^{\text {th }}$ Conf. Pest Control, NC. 357-365.

Jones, J.C. (1967): Normal differential counts of haemocytes in relation to ecodysis and feeding in Rhodnius. J. Insect Physiology, 13: 11331141.

Kostecki, R. (1965): Investigation on the haemocytes and haemolymph of honey bees. J. Apicult. Res. 4 (1): 49-54.

Kumar, M.D. and A. Michael (2011): Effect of Serifeed, a food supplement enriched feed of silkworm on its nutritional and economic parameters. Int. J. Sci. \& Engin. Res. 2: 9.

Manjula, S.; S. Selvi, S. Nadanam; and N. Saravanan (2011): Modifications in the haemolymph of silkworm fed with mulberry leaves augmented with cowpeas. Anamalia Nagar, 608, (1): 64-68.

Predtetshensky, V.E., V.M. Parovska and L.T. Margolina (1950): Goso Uzd. Medgez. Moskva (In Russian).

Radwan, M.A.S. (1978): The effect of castor plant fertilizers on the biochemical and properties of silk of the eri-worm. M.Sc. Cairo Univ., $103 \mathrm{pp}$.

Rateb; S.H.; M.H. Hussein; M.O. Mohamed and Heba R. Abdel-Karim (2010): Effect of some additives to mulberry leaves on larval haemolymph of silkworm (Bombyx mori L.). J. of Plant Protection and Pathology, Vol. 1 (3): 133-139.

Reddy, K.V.R.; O.R.R. Deri and K.V. Benchamin (1991): Impact of uzi fly parasitisation on the body growth, silk gland tissue somatic index and haemolymph properties of silkworm. Indian J. Seric., 30 (2): 113-120.

Salem, M.A., M.A. Eid and S.A.S. El-Maasarawy (1985a): Blood pattern in the Eri-silkworm, Philosamia ricini Boisd. under varied conditions (Lepidoptea, Saturniidae). Proc. $1^{\text {st }}$ Conf. PI. Prot. Res. Ins. Vol. II: 173-191.

Salem, M.S., M.A. Eid and S.A.S. El-Maasarawy (1985b): Quantitative analyses of blood pattern in the Eri-silkworm, Philosamia ricini Boisd., under varied conditions (Lepidoptea: Saturniidae). Proc. $1^{\text {st }}$ Conf. PI. Prot. Res. Ins. Vol. II: 193-209.

Thyagaraja, B.S., T.J. Kelly, E.P. Maslev and A.B. Brokovec (1991): Thyroxine-induced haemolymph protein and ecdystroid increase in the silkworm, Bombyx mori: Effect on larval growth and silk production. J. Insect. Physiol. 37 (2): 153-159.

Wigglesworth, V.B. (1959): Insect blood cells. Ann. Rev. Entomol. 4: 1-16. 


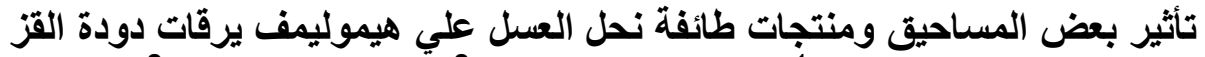

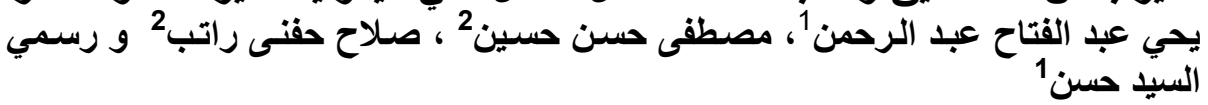
1- ققّم وقاية النبات ـ كلية الزراعة ـ جامعة الأزهر ، أسيوط. 2- قسم وقاية النبات ـ كلية الزراعة - جامعة أسيوط.

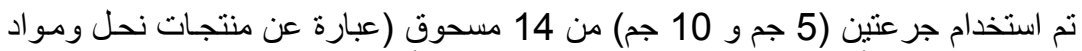

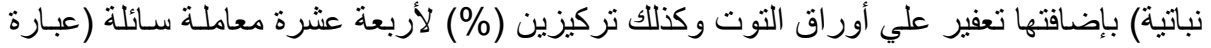

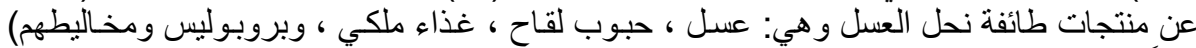

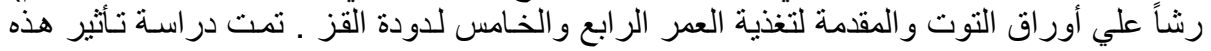

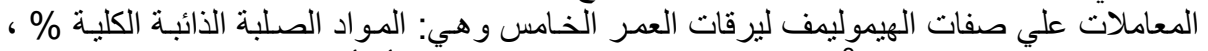

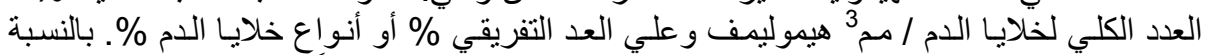

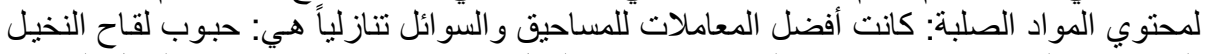

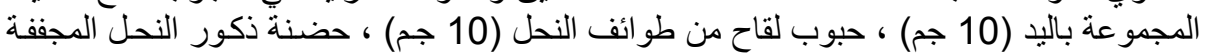

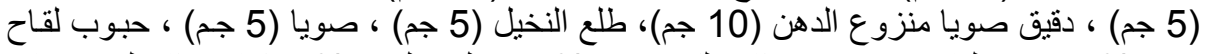

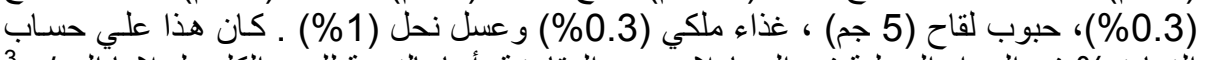

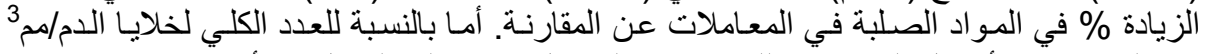

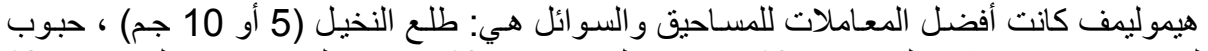

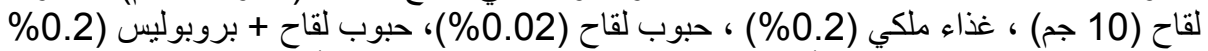

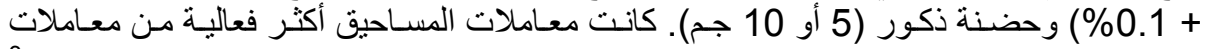

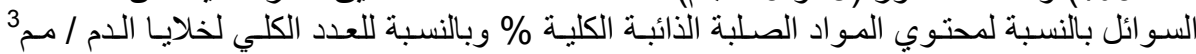

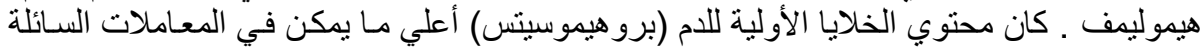

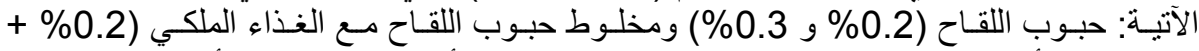

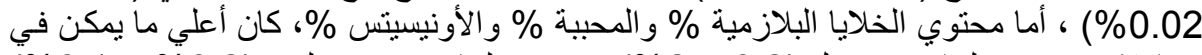

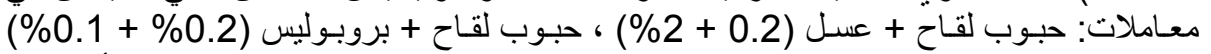

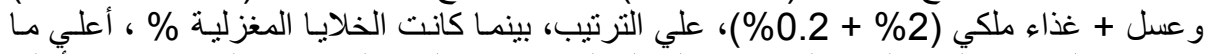

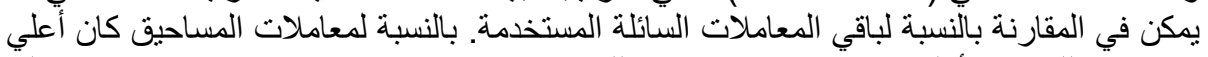

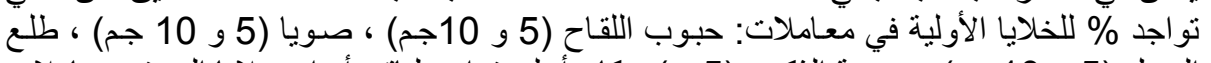

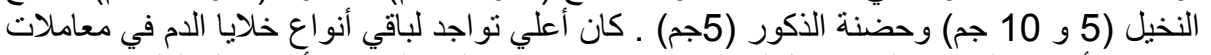

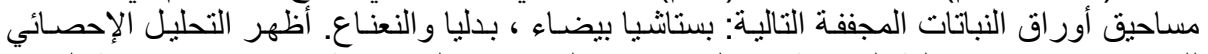

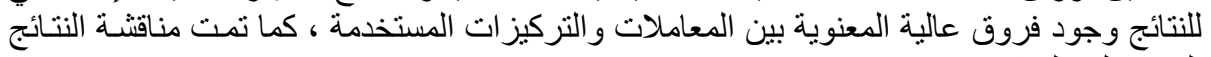

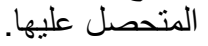

كلية الزراعة - جامعة المنصورة كلية الزراعة ـ جامعة القاهرة

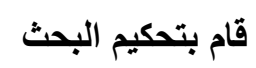

أ.د / أدبد البديع غانم أ.د / محمود السيد نور 
Abdel-Rahman, Y.A. et al. 
J. Plant Prot. and Path., Mansoura Univ., Vol. 3 (5), May, 2012 

J. Plant Prot. and Path., Mansoura Univ., Vol. 3 (5): 443 - 451, 2012

Table 1. Effect of tested powders on mean of haematological characters of $5^{\text {th }}$ instar larvae of silkworm.

\begin{tabular}{l|c|c|c|}
\hline Characters & T.S.S. \% & T.H.C. $/ \mathrm{mm}^{3}$ & Types of haemocytes (D.H.C.\%)
\end{tabular}

\begin{tabular}{|c|c|c|c|c|c|c|c|c|c|c|c|c|c|c|c|c|c|c|}
\hline \multirow{3}{*}{$\begin{array}{l}\text { Characters } \\
\text { (Dose) }\end{array}$} & \multicolumn{4}{|c|}{ T.S.S. \% } & \multicolumn{4}{|c|}{ T.H.C. $/ \mathrm{mm}^{3}$} & \multicolumn{10}{|c|}{ Types of haemocytes (D.H.C.\%) } \\
\hline & \multicolumn{2}{|c|}{ (5 gms) } & \multicolumn{2}{|c|}{ (10 gms) } & \multicolumn{2}{|c|}{ (5 gms) } & \multicolumn{2}{|c|}{ (10 gms) } & \multicolumn{5}{|c|}{ (5 gms) } & \multicolumn{5}{|c|}{ (10 gms) } \\
\hline & $\begin{array}{l}\text { ॠ } \\
\stackrel{\complement}{\Sigma}\end{array}$ & 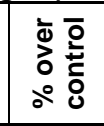 & ్ֻ & 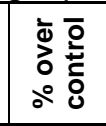 & 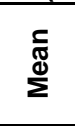 & $\begin{array}{l}\frac{1}{\Phi} \overline{0} \\
\text { वे } \\
\text { ○ }\end{array}$ & 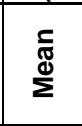 & 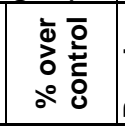 & 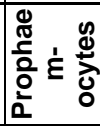 & 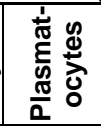 & 竞 & 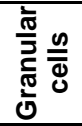 & 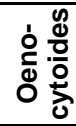 & 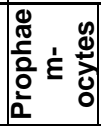 & 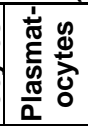 & 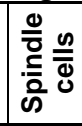 & $\begin{array}{l}\frac{1}{\frac{\pi}{3}} \\
\frac{0}{\frac{\pi}{\pi}} \\
\frac{\pi}{d} \\
\text { d }\end{array}$ & 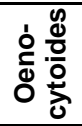 \\
\hline Pollen & $\begin{array}{c}12.90 \\
\mathrm{BC} \\
\end{array}$ & 22.159 & $\begin{array}{c}13.78 \\
A B\end{array}$ & 36.978 & $\begin{array}{l}2295 \\
\text { BCD }\end{array}$ & 94.326 & \begin{tabular}{|l|}
2443 \\
$A B C$
\end{tabular} & 122.495 & $\begin{array}{c}83.1 \\
A B\end{array}$ & $\begin{array}{c}3.9 \\
\mathrm{~J}\end{array}$ & $\begin{array}{c}5.8 \\
1\end{array}$ & $\begin{array}{l}4.3 \\
\text { LM }\end{array}$ & $\begin{array}{l}2.9 \\
D-I\end{array}$ & $\begin{array}{c}84.5 \\
A\end{array}$ & $\begin{array}{c}2.8 \\
\mathrm{~K}\end{array}$ & $\begin{array}{l}6.6 \\
\mathrm{HI}\end{array}$ & $\begin{array}{c}3.7 \\
M\end{array}$ & $\begin{array}{l}2.4 \\
\text { G-J }\end{array}$ \\
\hline Soya flour & \begin{tabular}{|c|}
13.74 \\
$A B$
\end{tabular} & 30.113 & $\begin{array}{c}13.29 \\
A B\end{array}$ & 32.107 & $\begin{array}{l}2288 \\
\text { BCD }\end{array}$ & 93.734 & \begin{tabular}{|l|}
2020 \\
DEF
\end{tabular} & 83.970 & $\begin{array}{l}81.4 \\
B C\end{array}$ & $\begin{array}{l}4.7 \\
D-J\end{array}$ & $\begin{array}{l}6.6 \\
\mathrm{HI}\end{array}$ & $\begin{array}{l}5.2 \\
\mathrm{KL}\end{array}$ & $\begin{array}{l}2.1 \\
\text { iJ }\end{array}$ & $\begin{array}{c}80.4 \\
C\end{array}$ & $\begin{array}{l}4.8 \\
\text { D-J }\end{array}$ & 5.9 & $\begin{array}{l}5.1 \\
\mathrm{KL}\end{array}$ & $\begin{array}{l}3.8 \\
A-D\end{array}$ \\
\hline rood Drones & $\begin{array}{c}12.52 \\
\mathrm{BC} \\
\end{array}$ & 18.560 & $\begin{array}{c}13.30 \\
A B\end{array}$ & 32.206 & $\begin{array}{l}2310 \\
\text { BCD }\end{array}$ & 95.596 & $\begin{array}{l}2125 \\
\text { CDE }\end{array}$ & 93.533 & $\begin{array}{c}77.1 \\
D\end{array}$ & $\begin{array}{l}5.5 \\
A-G\end{array}$ & $\begin{array}{l}6.9 \\
\mathrm{HI}\end{array}$ & 6.0 & $\begin{array}{c}4.5 \\
\text { A }\end{array}$ & $\begin{array}{l}79.7 \\
C D\end{array}$ & $\begin{array}{l}4.9 \\
\text { C-J }\end{array}$ & $\begin{array}{c}6.3 \\
1\end{array}$ & $\begin{array}{l}5.4 \\
\mathrm{KL}\end{array}$ & $\begin{array}{l}3.7 \\
A-D\end{array}$ \\
\hline Palm pollen & $\begin{array}{c}13.86 \\
A B \\
\end{array}$ & 31.250 & $\begin{array}{c}14.37 \\
\mathrm{~A}\end{array}$ & 42.842 & $\begin{array}{c}2591 \\
\text { AB }\end{array}$ & 119.390 & $\begin{array}{c}2736 \\
\text { A } \\
\end{array}$ & $149.180 \mid$ & $\begin{array}{c}80.2 \\
C\end{array}$ & $\begin{array}{l}4.8 \\
D-J\end{array}$ & $\begin{array}{r}6.7 \\
\mathrm{HI} \\
\end{array}$ & $\begin{array}{l}5.9 \\
\mathrm{JK}\end{array}$ & $\begin{array}{l}2.4 \\
\text { G-J }\end{array}$ & $\begin{array}{c}82.7 \\
\mathrm{AB}\end{array}$ & $\begin{array}{c}3.9 \\
\mathrm{~J}\end{array}$ & $\begin{array}{l}6.5 \\
\mathrm{HI}\end{array}$ & $\begin{array}{l}4.4 \\
\text { LM }\end{array}$ & $\begin{array}{l}2.5 \\
\text { E-J }\end{array}$ \\
\hline \begin{tabular}{ll|}
$5-$ & Ascorbic \\
acid & \\
\end{tabular} & $\begin{array}{c}12.65 \\
\mathrm{BC} \\
\end{array}$ & 19.791 & $\begin{array}{c}11.96 \\
C D \\
\end{array}$ & 18.886 & $\begin{array}{l}2193 \\
\mathrm{CDE}\end{array}$ & 85.690 & \begin{tabular}{|c|}
1905 \\
$\mathrm{EF}$ \\
\end{tabular} & 3.497 & $\begin{array}{c}77.7 \\
D\end{array}$ & 4.6 & $\begin{array}{c}7.6 \\
H\end{array}$ & $\begin{array}{l}6.6 \\
\text { IJ }\end{array}$ & $\begin{array}{l}3.5 \\
B-E\end{array}$ & $\begin{array}{c}74.0 \\
\mathrm{EF}\end{array}$ & $\begin{array}{l}5.1 \\
B-H\end{array}$ & $\begin{array}{c}9.9 \\
G\end{array}$ & $\begin{array}{l}7.2 \\
\mathrm{HI}\end{array}$ & $\begin{array}{l}3.8 \\
\text { A-D } \\
\end{array}$ \\
\hline $\operatorname{tana}$ & \begin{tabular}{|c|}
10.94 \\
DEF
\end{tabular} & 98 & \begin{tabular}{|c}
10.62 \\
$D-G$ \\
\end{tabular} & 5.566 & $\begin{array}{l}1695 \\
\text { FGH }\end{array}$ & 4 & $\begin{array}{c}1420 \\
\text { G-K }\end{array}$ & 326 & $\begin{array}{l}70.1 \\
\text { HIJ }\end{array}$ & $\begin{array}{l}5.0 \\
\text { B-I }\end{array}$ & $\begin{array}{l}12.5 \\
\mathrm{ABC}\end{array}$ & $\begin{array}{c}9.2 \\
\text { CDE }\end{array}$ & $\begin{array}{l}3.3 \\
B-G\end{array}$ & $\begin{array}{l}73.5 \\
\text { EFG }\end{array}$ & $\begin{array}{l}5.3 \\
\mathrm{~A}-\mathrm{H}\end{array}$ & $\begin{array}{c}10.5 \\
F G \\
\end{array}$ & $\begin{array}{l}7.0 \\
\text { HIJ }\end{array}$ & $\begin{array}{l}3.7 \\
A-D\end{array}$ \\
\hline Eucalyptus & $\begin{array}{c}11.16 \\
\mathrm{DE} \\
\end{array}$ & 5.681 & \begin{tabular}{|c}
10.89 \\
DEF \\
\end{tabular} & 8.250 & $\begin{array}{c}1740 \\
F G\end{array}$ & 47.332 & $\begin{array}{c}1401 \\
\text { G-K } \\
\end{array}$ & 27.595 & $\begin{array}{l}70.7 \\
\text { HIJ }\end{array}$ & $\begin{array}{l}5.4 \\
\text { A-G }\end{array}$ & $\begin{array}{l}11.5 \\
\text { C-F }\end{array}$ & $\begin{array}{c}9.3 \\
\text { CDE }\end{array}$ & $\begin{array}{l}3.1 \\
\text { B-I }\end{array}$ & $\begin{array}{l}71.5 \\
\text { F-J }\end{array}$ & $\begin{array}{l}5.0 \\
\text { B-I }\end{array}$ & $\begin{array}{l}11.6 \\
\mathrm{C}-\mathrm{F}\end{array}$ & & $\begin{array}{l}3.0 \\
\text { C-1 }\end{array}$ \\
\hline - Basil & $\begin{array}{c}10.57 \\
\text { EFG }\end{array}$ & 094 & $\begin{array}{c}9.02 \\
\mathrm{H}\end{array}$ & - & $\begin{array}{l}1068 \\
\text { KLM }\end{array}$ & - & $\begin{array}{c}850 \\
M\end{array}$ & - & $\begin{array}{c}69.6 \\
\text { IJ }\end{array}$ & & $\begin{array}{l}11.7 \\
\mathrm{CDE}\end{array}$ & $\begin{array}{l}8.6 \\
\text { C-G }\end{array}$ & $\begin{array}{l}4.1 \\
\mathrm{AB}\end{array}$ & $\begin{array}{c}70.0 \\
\text { HIJ }\end{array}$ & $\begin{array}{l}5.6 \\
\text { A-F }\end{array}$ & $\begin{array}{l}12.1 \\
\text { B-E }\end{array}$ & & $\begin{array}{l}3.8 \\
A-D\end{array}$ \\
\hline & & - & $\begin{array}{l}9.96 \\
\text { E-H }\end{array}$ & - & $\begin{array}{l}953 \\
\text { LM }\end{array}$ & - & $\begin{array}{l}918 \\
\text { LM } \\
\end{array}$ & - & $\begin{array}{c}69.3 \\
\text { IJ }\end{array}$ & 5.8 & $\begin{array}{l}11.6 \\
\mathrm{C}-\mathrm{F}\end{array}$ & $\begin{array}{l}9.4 \\
C D \\
\end{array}$ & $\begin{array}{r}3.9 \\
\text { A-D } \\
\end{array}$ & $\begin{array}{c}69.6 \\
\text { IJ }\end{array}$ & $\begin{array}{c}6.4 \\
\mathrm{~A}\end{array}$ & \begin{tabular}{|l}
11.8 \\
$\mathrm{CDE}$ \\
\end{tabular} & $\begin{array}{l}8.2 \\
\mathrm{E}-\mathrm{H}\end{array}$ & $\begin{array}{c}4.0 \\
A B C \\
\end{array}$ \\
\hline ime & & 3.977 & \begin{tabular}{|c|}
10.94 \\
$\mathrm{DEF}$ \\
\end{tabular} & 8.747 & $\begin{array}{c}1368 \\
\mathrm{H}-\mathrm{K}\end{array}$ & 15.834 & $\begin{array}{c}1441 \\
\text { G-J }\end{array}$ & 238 & $\begin{array}{c}69.2 \\
\text { IJ }\end{array}$ & 4.6 & 13.1 & 9.7 & 3.4 & 71.7 & $\begin{array}{c}6.4 \\
\mathrm{~A}\end{array}$ & $\begin{array}{l}11.2 \\
\text { DEF } \\
\end{array}$ & $\begin{array}{l}7.2 \\
\mathrm{HI}\end{array}$ & $\begin{array}{l}3.5 \\
\text { B-E }\end{array}$ \\
\hline - Ziziphus & 10.89 & 3.125 & $\begin{array}{c}10.76 \\
\mathrm{DEF}\end{array}$ & 6.958 & $\begin{array}{l}1391 \\
\text { G-K }\end{array}$ & 17.781 & $\begin{array}{c}1143 \\
\text { J-M }\end{array}$ & 4.098 & $\begin{array}{c}73.8 \\
E F\end{array}$ & $\begin{array}{l}4 . \\
\mathrm{G}\end{array}$ & $\begin{array}{c}10.4 \\
F G\end{array}$ & $\begin{array}{l}8.4 \\
D-G\end{array}$ & $\begin{array}{l}3.1 \\
\text { B-I }\end{array}$ & $\begin{array}{l}72.4 \\
E-H\end{array}$ & $\begin{array}{l}5.1 \\
\text { B-H }\end{array}$ & $\begin{array}{l}2.4 \\
-D\end{array}$ & $\begin{array}{l}7.8 \\
F-1\end{array}$ & $\begin{array}{l}2.3 \\
\text { G-J }\end{array}$ \\
\hline & & - & $\begin{array}{c}9.32 \\
\mathrm{GH}\end{array}$ & - & $\begin{array}{c}1190 \\
\text { I-M }\end{array}$ & 0.762 & $\begin{array}{l}930 \\
\text { LM } \\
\end{array}$ & - & $\begin{array}{l}69.9 \\
\text { HIJ }\end{array}$ & $\begin{array}{r}5.9 \\
\mathrm{ABC}\end{array}$ & $\begin{array}{l}11.6 \\
\text { C-F }\end{array}$ & $\begin{array}{l}8.7 \\
\text { C-G }\end{array}$ & $\begin{array}{r}3.9 \\
\text { A-D }\end{array}$ & $\begin{array}{l}71.1 \\
\text { G-J }\end{array}$ & $\begin{array}{l}4.7 \\
\text { D-J }\end{array}$ & \begin{tabular}{|l|}
12.4 \\
$A-D$ \\
\end{tabular} & 9.5 & $\begin{array}{l}2.3 \\
\text { G-J }\end{array}$ \\
\hline 13- Vasaka & 10.08 & - & \begin{tabular}{|c|c|}
10.18 \\
E-H
\end{tabular} & 192 & $\begin{array}{l}1266 \\
\text { IJKL }\end{array}$ & 7.197 & $\begin{array}{c}1146 \\
\text { J-M } \\
\end{array}$ & 37 & $\begin{array}{c}68.9 \\
\mathrm{~J}\end{array}$ & & $\begin{array}{c}13.3 \\
\mathrm{~A} \\
\end{array}$ & $\begin{array}{l}9.8 \\
\text { BC } \\
\end{array}$ & $\begin{array}{l}3.4 \\
\text { B-F }\end{array}$ & $\begin{array}{l}70.4 \\
\text { HIJ }\end{array}$ & $\begin{array}{l}4.2 \\
\text { HIJ } \\
\end{array}$ & $\begin{array}{l}12.0 \\
\text { B-E } \\
\end{array}$ & $\begin{array}{c}10.9 \\
\mathrm{~A}\end{array}$ & $\begin{array}{l}2.5 \\
\text { E-J }\end{array}$ \\
\hline 4- Guava & 10.80 & 2.272 & $\begin{array}{c}11.08 \\
D E\end{array}$ & $\mid 10.139$ & $\begin{array}{l}1535 \\
\mathrm{GHI}\end{array}$ & 29.974 & $\begin{array}{l}1700 \\
\text { FGH }\end{array}$ & 54.826 & $\begin{array}{c}74.4 \\
\mathrm{E}\end{array}$ & 4.3 & 11.5 & 7.6 & $\begin{array}{l}2.2 \\
\text { HIJ }\end{array}$ & $\begin{array}{l}73.5 \\
\text { EFG }\end{array}$ & $\begin{array}{l}5.4 \\
A-G\end{array}$ & \begin{tabular}{|l|}
10.9 \\
EFG \\
\end{tabular} & $\begin{array}{c}8.5 \\
C-G\end{array}$ & $\begin{array}{l}1.7 \\
\text { HIJ }\end{array}$ \\
\hline & & 0 & \begin{tabular}{|c}
10.06 \\
E-H \\
\end{tabular} & 0 & & 0 & $\begin{array}{c}1098 \\
\text { J-M } \\
\end{array}$ & 0 & $\begin{array}{l}70.2 \\
\text { HIJ }\end{array}$ & 4.6 & $\begin{array}{l}12.0 \\
\text { B-E }\end{array}$ & $\begin{array}{c}10.7 \\
A B \\
\end{array}$ & $\begin{array}{l}2.5 \\
\text { E-J }\end{array}$ & $\begin{array}{l}71.0 \\
\text { HIJ }\end{array}$ & $\begin{array}{l}5.7 \\
\text { A-E }\end{array}$ & $\begin{array}{l}11.9 \\
\mathrm{CDE} \\
\end{array}$ & $\begin{array}{l}8.2 \\
\text { E-H }\end{array}$ & $\begin{array}{l}3.2 \\
\text { B-H }\end{array}$ \\
\hline 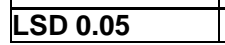 & & & & & & & & & 2.181 & 936 & 02 & 05 & 90 & 218 & 00 & 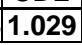 & 05 & 86 \\
\hline
\end{tabular}

Means in a column followed by the same letter are not significantly different at 0.05 level of probability. 
Abdel-Rahman, Y.A. et al.

Table 2. Effect of hive products liquids on mean of haematological characters of $5^{\text {th }}$ instar larvae of silkworm.

\begin{tabular}{|c|c|c|c|c|c|c|c|c|c|}
\hline \multirow{2}{*}{\begin{tabular}{|c|} 
Hive products \\
(con., gm/100 ml distilled \\
water) \\
\end{tabular}} & \multicolumn{2}{|c|}{ T.S.S. \% } & \multicolumn{2}{|c|}{ T.H.C. $/ \mathrm{mm}^{3}$} & \multicolumn{5}{|c|}{ Types of haemocytes (D.H.C.\%) } \\
\hline & Mean & $\begin{array}{l}\text { \% over } \\
\text { control }\end{array}$ & Mean & $\begin{array}{l}\% \text { over } \\
\text { control }\end{array}$ & $\begin{array}{l}\text { Prophaem- } \\
\text { ocytes }\end{array}$ & $\begin{array}{l}\text { Plasmat- } \\
\text { ocytes }\end{array}$ & $\begin{array}{c}\text { Spindle } \\
\text { cells }\end{array}$ & $\begin{array}{c}\text { Granular } \\
\text { cells }\end{array}$ & $\begin{array}{c}\text { Oeno- } \\
\text { cytoides }\end{array}$ \\
\hline 1- Honey (1 gm) & $11.66 \mathrm{ABC}$ & 15.904 & $2133 \mathrm{AB}$ & 80.609 & $76.5 \mathrm{CD}$ & $4.6 \mathrm{CDE}$ & $8.2 \mathrm{D}$ & $6.8 \mathrm{EF}$ & $3.9 \mathrm{AB}$ \\
\hline 2- Honey (2 gm) & $10.05 \mathrm{CD}$ & - & $1810 \mathrm{CD}$ & 53.259 & 73.8 FGH & 4.3 D-G & $10.4 \mathrm{C}$ & $8.8 \mathrm{~B}$ & 2.7 DEF \\
\hline 3- Royal jelly (0.02 gm) & $10.50 \mathrm{CD}$ & 4.373 & $2353 \mathrm{~A}$ & 99.237 & $80.9 \mathrm{~B}$ & $4.5 \mathrm{C}-\mathrm{F}$ & $5.8 \mathrm{E}$ & $5.1 \mathrm{G}$ & $3.7 \mathrm{ABC}$ \\
\hline 4- Royal jelly $(0.03 \mathrm{gm})$ & $12.27 \mathrm{AB}$ & 21.998 & 2046 BC & 73.243 & $76.4 \mathrm{CD}$ & $4.8 \mathrm{CDE}$ & $7.9 \mathrm{D}$ & $7.1 \mathrm{DE}$ & $3.8 \mathrm{AB}$ \\
\hline 5- Propolis (0.1 gm) & $10.08 \mathrm{CD}$ & 0.198 & $1670 \mathrm{D}$ & 41.405 & $76.6 \mathrm{CD}$ & $5.0 \mathrm{BCD}$ & $8.1 \mathrm{D}$ & $6.3 \mathrm{EF}$ & $4.0 \mathrm{AB}$ \\
\hline 6- Propolis (0.2 gm) & $9.62 \mathrm{D}$ & - & $1160 \mathrm{E}$ & 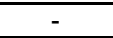 & $72.4 \mathrm{GHI}$ & 3.7 FGH & $11.8 \mathrm{AB}$ & $9.8 \mathrm{AB}$ & $2.3 \mathrm{EFG}$ \\
\hline 7- Pollen (0.2 gm) & $11.48 \mathrm{BCD}$ & 14.15 & $2345 \mathrm{~A}$ & 98.560 & $85.2 \mathrm{~A}$ & $3.3 \mathrm{H}$ & $5.1 \mathrm{E}$ & $3.6 \mathrm{H}$ & $2.8 \mathrm{CDE}$ \\
\hline 8- Pollen $(0.3 \mathrm{gm})$ & $13.08 \mathrm{~A}$ & 30.019 & $1940 \mathrm{BC}$ & 64.267 & $82.6 \mathrm{~B}$ & 4.2 D-G & $6.0 \mathrm{E}$ & $5.4 \mathrm{G}$ & $1.8 \mathrm{FG}$ \\
\hline $\begin{array}{l}\text { 9- Pollen + Royal jelly } \\
(0.2+0.02 \mathrm{gm})\end{array}$ & $11.41 \mathrm{BCD}$ & 13.449 & 2093 AB & 77.222 & $81.0 \mathrm{~B}$ & $3.5 \mathrm{GH}$ & $7.7 \mathrm{D}$ & $5.1 \mathrm{G}$ & 2.7 DEF \\
\hline $\begin{array}{l}\text { 10- Pollen + Honey } \\
(0.2+2 \mathrm{gm}) \\
\end{array}$ & $10.60 \mathrm{CD}$ & 5.427 & $1138 \mathrm{E}$ & - & 74.1 EFG & $5.8 \mathrm{~A}$ & $10.2 \mathrm{C}$ & $7.6 \mathrm{CD}$ & 2.3 EFG \\
\hline $\begin{array}{l}\text { 11- Pollen + Propolis } \\
(0.2+0.1 \mathrm{gm})\end{array}$ & $11.03 \mathrm{BCD}$ & 9.671 & $2333 \mathrm{~A}$ & 97.544 & $72.0 \mathrm{HI}$ & $4.2 \mathrm{D}-\mathrm{G}$ & $12.3 \mathrm{~A}$ & $10.0 \mathrm{~A}$ & $1.5 \mathrm{G}$ \\
\hline $\begin{array}{l}\text { 12- Pollen + Propolis } \\
(2+0.1 \mathrm{gm})\end{array}$ & $9.80 \mathrm{D}$ & - & $973 \mathrm{E}$ & - & 74.7 DEF & 4.8 CDE & $11.1 \mathrm{BC}$ & $6.0 \mathrm{FG}$ & $3.4 \mathrm{~A}-\mathrm{D}$ \\
\hline $\begin{array}{l}\text { 13- Propolis + Royal Jelly } \\
(2+0.02 \mathrm{gm})\end{array}$ & $10.54 \mathrm{CD}$ & 4.771 & $1163 \mathrm{E}$ & - & 76.0 CDE & $5.1 \mathrm{ABC}$ & $8.1 \mathrm{D}$ & 6.6 EF & $4.2 \mathrm{~A}$ \\
\hline $\begin{array}{l}\text { 14- Propolis + Royal Jelly } \\
(0.1+0.02 \mathrm{gm})\end{array}$ & $10.26 \mathrm{CD}$ & 2.047 & 2043 BC & 72.988 & $77.0 \mathrm{C}$ & $5.7 \mathrm{AB}$ & $8.4 \mathrm{D}$ & 4.9 FG & $4.0 \mathrm{AB}$ \\
\hline 15- Control & $10.06 \mathrm{CD}$ & 0 & $1181 \mathrm{E}$ & 0 & 71.01 & $5.7 \mathrm{AB}$ & $11.9 \mathrm{AB}$ & $8.2 \mathrm{C}$ & $3.2 \mathrm{BCD}$ \\
\hline LSD 0.05 & 0.9 & & & & 1.888 & 0.7646 & 0.9252 & 0.8329 & 0.8707 \\
\hline
\end{tabular}

0.972

\begin{tabular}{l|l}
71.01 & $5.7 \mathrm{AB}$ \\
\hline .888 & 0.7646
\end{tabular}

Means in a column followed by the same letter are not significantly different at 0.05 level of probability. 
J. Plant Prot. and Path., Mansoura Univ., Vol. 3 (5): 443 - 451, 2012 